\title{
Keterkaitan Komunitas Makrozoobentos dengan Kualitas Air dan Substrat di Ekosistem Mangrove Taman Hutan Raya Ngurah Rai Bali
}

\author{
Maria Ulfa ${ }^{\text {**, }}$ Pande Gde Sasmita Julyantoro a , Alfi Hermawati Waskita Sari a \\ a Program Studi Manajemen Sumberdaya Perairan, Fakultas Kelautan dan Perikanan, Universitas Udayana, Bukit Jimbaran, Bali-Indonesia \\ * Penulis koresponden. Tel.: +62-857-4608-6815 \\ Alamat e-mail: ma.ulfa@yahoo.com
}

Diterima (received) 30 Juli 2017; disetujui (accepted) 29 Oktober 2017; tersedia secara online (available online) 31 Oktober 2017

\begin{abstract}
Ngurah Rai forest park located in two districts of Badung and Denpasar city which is as the main centre of anthropogenic activities. There is an estuary in this area that used as run off of those activities. This area faces directly into the ocean. Wastes from anthropogenic activities indirectly affected biotic and abiotic components such as water quality, substrate, and macrozoobenthos. This research aims to discover the community of macrozoobenthos and its relation to the water quality and substrate in Ngurah Rai forest park. This research used purposive sampling metode to determine of stations. Sampling was conducted at four different stations covering macrozoobenthos samples, measuring water quality (salinity, $\mathrm{pH}, \mathrm{DO}$, temperature, turbidity) and substrate samples. A total of 19 types of macrozoobenthos was found out of 5 classes, i.e. Polychaeta, Oligochaeta, Bivalves, Gastropods, and Crustaceans. The diversity index was categorized as low to moderate. The uniformity index value of community was categorized as balanced. The dominant index on the fourth station states that the level of dominance was categorized as low. Water quality parameter measurement results were still within normal limits, but the turbidity value of the first station exceeds the normal limits due to high content of organic matter. The substrate type at first station to fourth station were sandy clay loam, sandy loam, clay loam, and sandy loam respectively. Temperature, salinity, turbidity were the parameters that greatly affected the abundance of macrozoobenthos, while substrates such as sand and clay have a major influence on the abundance of macrozoobenthos.
\end{abstract}

Keywords: macrozoobentos; Ngurah Rai forest park; substrate; water quality

\begin{abstract}
Abstrak
Tahura Ngurah Rai berada di dua kabupaten kota yaitu kabupaten Badung dan Denpasar yang merupakan kawasan pusat kegiatan antropogenik. Dimana kawasan ini merupakan kawasan buangan limbah yang berhadapan langsung dengan laut. Hasil buangan limbah dari kegiatan antropogenik secara tidak langsung mempengaruhi komponen biotik dan abiotik seperti makrozoobentos, kualitas perairan dan substrat. Tujuan penelitian ini yaitu untuk mengetahui kaitan keberadaan komunitas makrozoobentos dengan kualitas air dan substrat di Tahura Ngurah Rai. Penelitian ini menggunakan metode deskriptif kuantitatif penentuan stasiun menggunakan metode purposive sampling. Pengambilan sampel dilakukan di 4 stasiun yang meliputi sampel makrozoobentos, pengukuran kualitas perairan (salinitas, $\mathrm{pH}, \mathrm{DO}$, suhu, kekeruhan) dan sampel substrat. Makrozoobentos di Tahura Ngurah Rai ditemukan 19 jenis dari 5 kelas yaitu Polychaeta, Oligochaete, Bivalvia, Gastropoda, Crustacea. Indeks keanekaragaman yang masuk dalam kategori rendah sampai sedang. Nilai indeks keseragaman dalam kategori komunitas stabil. Indeks dominansi pada ke-4 stasiun yaitu menyatakan bahwa tingkat dominasi rendah. Hasil pengukuran parameter kualitas air masih dalam batas normal kecuali nilai kekeruahan pada stasiun I yang melebihi batas normal akibat kandungan bahan organik yang tinggi. Tipe substrat pada stasiun I sampai stasiun IV berturutturut adalah lempung liat berpasir, lempung berpasir, lempung berliat, lempung berpasir. Parameter kualitas air yang paling berpengaruh terhadap kelimpahan makrozoobentos adalah suhu, salinitas dan kekeruhan. Sedangkan substrat yang memiliki pengaruh besar terhadap kelimpahan makrozoobentos adalah pasir dan liat.
\end{abstract}

Kata Kunci: kualitas air; makrozoobentos; substrat; taman hutan raya Ngurah Rai 


\section{Pendahuluan}

Ekosistem Mangrove di Indonesia memiliki wilayah terluas di dunia yang berkisar 4,2 juta ha dan tersebar di kawasan yang di pengaruhi pasang surut air laut (Tarigan, 2010). Salah satu ekosistem mangrove di Indonesia terdapat di Taman Hutan Raya (TAHURA) Ngurah Rai merupakan suatu kawasan hutan bertipe hutan payau. Hutan jenis ini sangat dipengaruhi oleh keadaan pasang surut air laut.

Keberadaan Taman Hutan Raya Ngurah Rai ditetapkan berdasarkan surat keputusan Menteri Kehutanan pada Tahun 1993 yang menetapkan taman ini dengan luas sekitar 1373,5 ha. Secara administrasi Taman Hutan Raya Ngurah Rai berada dua kabupaten kota yaitu kabupaten Badung dan Kota Denpasar. Kawasan Taman Hutan Raya Ngurah Rai ini dikelilingi oleh perumahan, restaurant, perhotelan, mall, dan pertokoan sebagai pusat kegiatan manusia selain itu juga terdapat muara sungai yang merupakan saluran buangan dari kegiatan- kegiatan tersebut Rumada et al.,(2015).

Alih fungsi lahan, keberadaan sampah dan keadaan air yang tercemar merupakan masalah utama yang menyebabkan tertekannya pertumbuhan dan perkembangan ekosistem mangrove di Taman Hutan Raya Ngurah Rai. Tertekannya perkembangan mangrove sangat berpengaruh terhadap komponen penyusun didalam ekosistem tersebut. Ekosistem mangrove terdiri dari komponen biotik dan abiotik. Komponen abiotik dan biotik ini saling terkait satu sama lain. Komponen biotik meliputi flora dan fauna yang mendiami kawasan tersebut. Salah satunya adalah komunitas makrozoobentos yang hidup di dasar perairan atau di substrat. Sehingga hidupnya dipengaruhi oleh kondisi substrat dan kualitas perairan dikawasan tersebut. Makrozoobentos merupakan kelompok biota yang hidupnya menetap (sesil) dan juga merupakan deposit feeder (pengakumulasi) serta filter feeder (penyaring) yang dapat mengakumulasi suatu bahan pencemar di dalam tubuhnya.

Menurut Septiani (2015), makrozoobentos merupakan salah satu komunitas biota yang sering dipakai sebagai bioindikator pencemaran di suatu perairan. Hal ini berdasarkan cara hidup makrozoobentos yang hidup menetap (sesil) dan tingkat mobilitasnya rendah sehingga dapat digunakan untuk menduga kualitas suatu perairan dimana komunitas organisme tersebut berada. Tujuan penelitian ini yaitu untuk mengetahui komunitas makrozoobentos serta kaitannya dengan kualitas air dan substrat di Tahura Ngurah Rai. Oleh karena itu penelitian mengenai keterkaitan struktur komunitas makrozoobentos dengan kualitas air dan substrat di ekosistem mangrove Taman Hutan Raya Ngurah Rai, Desa Pamogan, Denpasar penting dilakukan sebagai bahan informasi untuk pengelolaan ekosistem mangrove Taman Hutan Raya Ngurah Rai.

\section{Metode Penelitian}

\subsection{Waktu dan tempat}

Penelitian ini dilaksanakan di ekosistem Mangrove Taman Hutan Raya (TAHURA) Ngurah Rai, Desa Pamogan, Denpasar, Bali pada bulan Februari sampai bulan Maret 2017. Parameter kualitas air yang diukur yaitu suhu, $\mathrm{pH}, \mathrm{DO}$ (dissolve oxygen), salinitas, dan kekeruhan. Pengambilan dan pengukuran sampel air dilakukan secara in situ dengan pengulangan 3 kali agar data kualitas air yang diambil valid (Mentari dan Muskananfola, 2015). Sedangkan Identifikasi makrozoobentos dilakukan secara in situ dan eksitu di Laboratorium Manajemen Sumberdaya Perairan Fakultas Kelautan dan Perikanan Universitas Udayana. Analisis tipe substrat dilaksanakan di Laboratorium Fisika dan Kimia Tanah, Fakultas Pertanian Universitas Udayana. Stasiun penelitian di kawasan Taman Hutan Raya Ngurah dipilih 4 stasiun:

\subsection{Metode Penelitian}

Penelitian mengenai keterkaitan komunitas makrozoobentos dengan kualitas air dan substrat dilakukan dengan metode deskriptif kuantitatif. Untuk metode penentuan stasiun menggunakan metode purposive sampling yaitu penentuan stasiun dengan pertimbangan tertentu. Pada 4 stasiun diambil 3 titik sebagai pengulangan dengan jarak masing-masing titik sejauh $20 \mathrm{~m}$.

Pengambilan sampel pada masing-masing titik menggunakan transek kuadran yang berukuran $1 \mathrm{~m} \times 1 \mathrm{~m}$. Transek kuadran tersebut dibagi menjadi 9 plot, dan pengamatan dilakukan pada 5 plot yang telah ditentukan. Parameter yang diamati pada setiap titik adalah kualitas air, sampel 


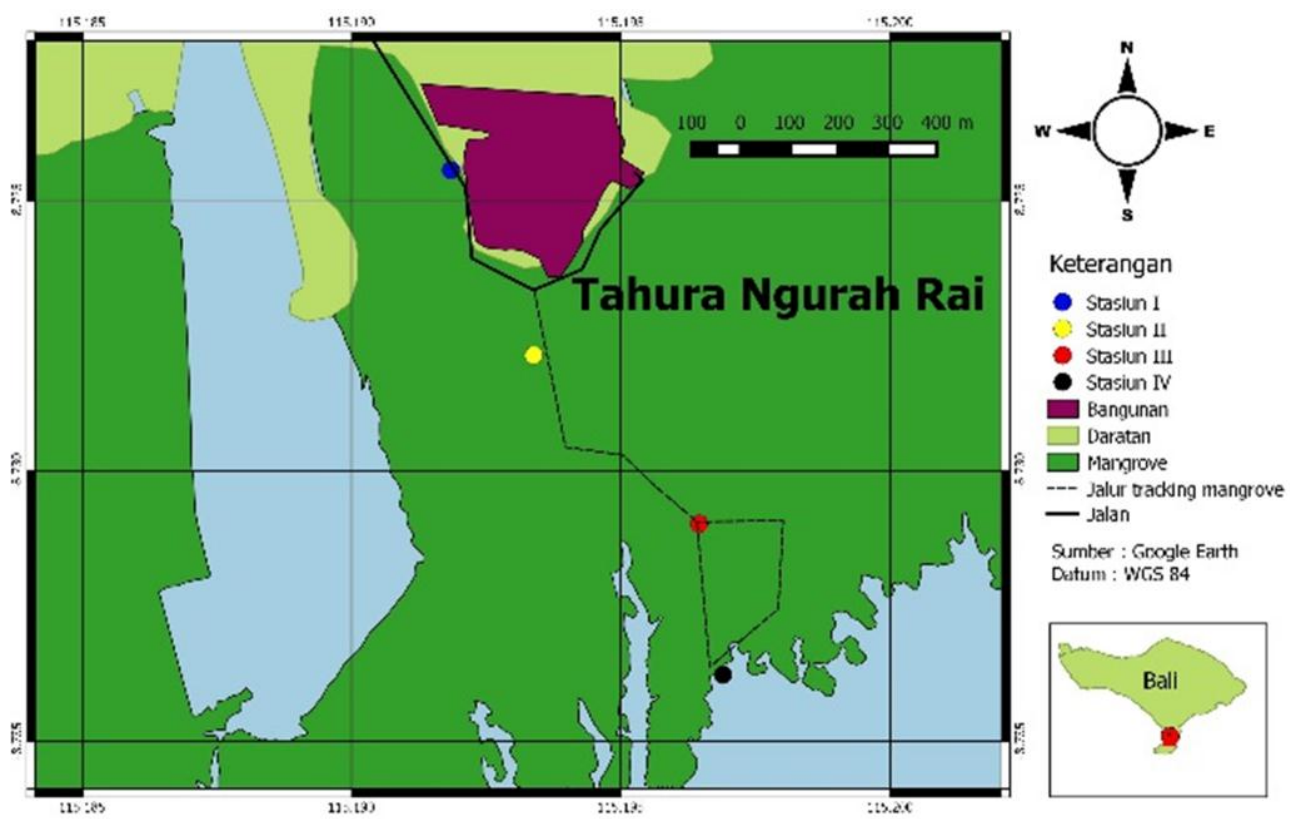

Gambar 1. Peta Lokasi Penelitian

substrat dan menghitung jumlah makrozoobentos yang ada pada transek.

Langkah-langkah untuk pengambilan sampel makrozoobentos, substrat dan air di ekosistem Mangrove Taman Hutan Raya Ngurah Rai yaitu:

\section{a. Sampel Kualitas Air}

Menyesuaikan pengambilan sampel di koordinat yang telah ditentukan dengan menggunakan GPS. Sampel air diambil dengan menggunakan botol plastik. Pengukuran $\mathrm{pH}$ air dengan menggunakan $\mathrm{pH}$ meter. Pengukuran suhu air dengan menggunakan termometer. Pengukuran salinitas air dengan menggunakan refraktometer. Pengukuran DO menggunakan DO meter. Pengukuran kekeruhan diukur dengan turbidity meter.

\section{b. Sampel Substrat}

Identifikasi substrat diawali dengan pengambilan sampel substrat dilakukan dengan menggunakan pipa corer pada masing-masing stasiun, kemudian dikeringkan dan dibawa ke lab. Ilmu Tanah FP UNUD untuk diidentifikasi.

\section{c. Sampel Makrozoobentos}

Pengambilan sampel makrozoobentos dengan menggunakan transek kuadran yang dibagi menjadi 9 plot, dalam satu titik hanya diambil pada 5 plot dengan pipa corer. Menyaring sampel makrozoobentos dengan menggunakan jaring yang berukuran $0,5 \mathrm{~mm}$ kemudian menggunakan jaring berukuran 0,1 mm. Megidentifikasi jenis makrozoobentos dengan menggunakan buku identifikasi Encyclopedia of Marine Gastropods.

\subsection{Alat dan Bahan}

Alat dan bahan yang dibutuhkan dalam penelitian yaitu GPS (Global Position System), sepatu boot, transek kuadran, saringan, $\mathrm{pH}$ pen, termometer, refraktometer, DO meter, turbidity meter, kantong plastic, kertas label, spidol, kamera, toples plastic, penjepit, akuades, formalin $10 \%$, sampel air, sampel substrat, sampel makrozoobentos, dan buku identifikasi makrozoobentos.

\subsection{Analisis Data}

\subsubsection{Komposisi Makrozoobentos}

Kekayaan makrozoobentos di badan perairan apat digambarkan dengan menggunkan komposisi makrozoobentos. Komposisi makrozoobentos dinyatakan dengan presentase (\%) sebagai pembanding antar genus dari jumlah total makrozoobentos (Setiawan, 2008). Persamaan untuk menentukan komposisi jenis:

$K j=\frac{n i}{N} X 100 \%$

\section{Keterangan:}

$\mathrm{Kj}$ : Komposisi jenis

ni : Jumlah individu jenis ke- $\mathrm{i}$

$\mathrm{N}$ : Jumlah individu semua jenis 
Tabel 1.

Lokasi Pengambilan Sampel Penelitian

\begin{tabular}{|c|c|c|c|}
\hline No & Stasiun & Titik Koordinat & Gambaran Lokasi \\
\hline 1. & Stasiun I & $\begin{array}{l}\text { S : } 0843^{\prime} 27.8^{\prime \prime} \\
\text { E : } 11511 ' 30.9^{\prime \prime}\end{array}$ & $\begin{array}{l}\text { Terletak di bagian utara atau setelah pintu masuk Kantor } \\
\text { yang merupakan kawasan pemukiman penduduk. }\end{array}$ \\
\hline 2. & Stasiun II & $\begin{array}{l}\text { S : } 0843^{\prime} 41.4^{\prime \prime} \\
\text { E : } 11511^{\prime} 36.4^{\prime \prime}\end{array}$ & $\begin{array}{l}\text { Terletak di bagian barat wilayah Ekosistem Mangrove Taman } \\
\text { Hutan Raya (TAHURA) Ngurah Rai, yang merupakan muara } \\
\text { sungai. }\end{array}$ \\
\hline 3. & Stasiun III & $\begin{array}{l}S: 0843^{\prime} 54.2^{\prime \prime} \\
\text { E : } 11511^{\prime} 43^{\prime \prime} 3\end{array}$ & $\begin{array}{l}\text { Terletak di kawasan tengah Ekosistem Mangrove Taman } \\
\text { Hutan Raya (TAHURA) Ngurah Rai, lokasi ini tidak } \\
\text { terpengaruh oleh aktifitas manusia. }\end{array}$ \\
\hline 4. & Stasiun IV & $\begin{array}{l}\text { S: } 08044^{\prime} 1,4^{\prime \prime} \\
\text { E : } 11511^{\prime} 48.8^{\prime \prime}\end{array}$ & $\begin{array}{l}\text { Terletak di sebelah selatan atau area depan Ekosistem } \\
\text { Mangrove Taman Hutan Raya (TAHURA) Ngurah Rai yang } \\
\text { berhubungan langsung dengan laut an dekat dengan Tol Bali } \\
\text { Mandara. }\end{array}$ \\
\hline
\end{tabular}

\subsubsection{Kelimpahan}

Kelimpahan dihitung untuk mendapatkan gambaran berapa jumlah makrozoobentos dalam satuan meter persegi $\left(\mathrm{m}^{2}\right)$. Kelimpahan dihitung dengan rumus:

$D i=\frac{n i}{A}$

Keterangan:

Di : Kelimpahan individu jenis ke- $\mathrm{i}\left(\mathrm{ind} / \mathrm{m}^{2}\right)$

ni : Jumlah individu ke- I (ind)

A : Luas kotak pengambilan sampel $\left(\mathrm{m}^{2}\right)$

\subsubsection{Indeks Keanekaragaman}

Gambaran populasi organisme secara sistematis didapatkan dengan menggunkan indeks keanekaragaman $\left(\mathrm{H}^{\prime}\right)$ agar mempermudah analisa informasi jumlah individu masing-masing spesies dalam suatu organisme (Odum, 1994). Indeks keanekaragaman jenis dihitung dengan formulasi Shannon (English et al.,1994):

$H^{\prime}=-\sum_{i=1}^{n} P i \ln P i$

Keterangan:

$\mathrm{H}^{\prime}$ : Indeks Keanekaragaman Shannon- Wiener

$\mathrm{Pi}$ : Perbandingan antara jumlah individu spesies ke- i (ni) dengan jumlah individu (N)

I $\quad: 1,2,3, \ldots \mathrm{n}$

\subsubsection{Indeks Keseragaman}

Indeks keseragaman dihitung untuk mengetahui keseragaman jenis makrozoobentos yang ada di wilayah perairan. Indeks keseragaman berkisar antara 0-1 dan nilai indeks kesereagaman ini dapat mengetahui kualitas perairan. Nilai indeks keseragaman dapat ditemukan dengan menggunakan rumus indeks keseragaman Shanon- Wiener (Odum, 1994):

$e=\frac{H^{\prime}}{H \text { maks }}$

Keterangan:

e : Indeks keseragaman

$\mathrm{S} \quad$ : Banyak jenis yang ditemukan

$\mathrm{H}^{\prime} \quad$ : Indeks Keseragaman

H maks : $\ln S$

\subsubsection{Indeks Dominansi}

Indeks dominansi ini digunakan untuk menggambarkan bagaimana salah satu spesies dapat mendominasi dalam suatu populasi tersebut. Spesies yang paling mendominasi dapat menentukan kehadiran spesies lain berdasarkan indeks dominansi Simpson (Odum, 1993):

$C=\sum_{i=1}^{n}\left(\frac{n i}{N}\right)^{2}$

Keterangan:

C : Indeks Dominansi

$\mathrm{Ni} \quad$ : Jumlah Individu jenis ke-i

$\mathrm{N} \quad$ : Jumlah total individu

2.5 Analisis Keterkaitan Makrozoobentos dengan Kualitas Air dan Substrat

Analisis yang digunakan untuk mengetahui keterkaitan makrozoobentos dengan kualitas air 
dan tipe substrat adalah dengan menggunakan analisis korelasi (Sugiyono, 2005). Untuk melihat keterkaitan makrozoobentos dengan kualitas air dan tipe substrat digunakan analisis regresi linier sederhana menggunakan Ms. Excel. Variabel bebas (tidak terikat) diberi notasi $\mathrm{X}$ yang merupakan kualitas air dan tipe substrat. Variable yang tidak bebas (terikat) diberi notasi $\mathrm{Y}$ adalah makrozoobentos. Analisis korelasi dapat dilihat sebagai berikut:

$\mathbf{r}_{\mathrm{xy}}=\frac{N x\left(\sum X_{i} Y_{i}\right)-\left(\sum X_{i} \sum Y_{i}\right)}{\sqrt{\left(N \sum X_{i}^{2}-\left(\sum X_{i}\right)^{2}\right)\left(N \sum Y_{i}^{2}-\left(\sum Y_{i}\right)^{2}\right)}}$

$r_{x y}:$ Koefisien kelimpahan makrozoobentos terhadap parameter kualitas air/ substrat

x : Parameter kualitas air atau substrat

y : Kelimpahan makrozoobentos

$\mathrm{N}$ : Jumlah data

Untuk mengetahui seberapa besar pengaruh kualitas air dan tipe substrat terhadap kepadatan makrozoobentos dilakukan analisis regresi. Analisis regresi dapat dilihat sebagai berikut:

$\bar{Y}=a+b x$

Dimana:

$\alpha=\frac{\left(\sum y\right) \sum x^{2}-\left(\sum x\right)\left(\sum x y\right)}{n \sum x^{2}-\left(\sum x\right)^{2}}$

$b=\frac{n \sum x y-\left(\sum x\right)\left(\sum y\right)}{n \sum x^{2}-\left(\sum x\right)^{2}}$

Keterangan:

$\overline{\mathrm{Y}}$ : Peubah tak bebas

$\mathrm{x}$ : Peubah bebas

a : Perpotongan sumbu y bila nilai $x=0$

$\mathrm{b}$ : Nilai perubah variabel y bila variabel $\mathrm{x}$ berubah satu satuan

$R^{2}=\frac{a \sum y+b \sum x y-n(\bar{Y})^{2}}{\sum y^{2}-n(\bar{Y})^{2}}$

\section{Hasil dan Pembahasan}

\subsection{Makrozoobentos}

\subsubsection{Komposisi Jenis Makrozoobentos}

Hasil dari penelitian di kawasan Taman Hutan Raya Ngurah Rai ditemukan 19 spesies yang tersebar di 4 stasiun. Jumlah total individu yang ditemukan sebanyak 132 individu. Spesies yang ditemukan di Tahura Ngurah Rai terdiri dari 5 kelas yaitu polychaeta, oligochaeta, bivalvia, gastropoda, dan crustacea.

Presentase spesies yang ditemukan yaitu Nereis sp. sebanyak 6\%, Lumbricus rubellus 7\%, Isognomon sp. 2\%, Tellina sp. 2\%, Pinctada sp. 2\%, Telescopium telescopium 7\%, Terebralia sulcata 11\%, Nassarius reevanus 5\%, Chicoreus capucinus 4\%, Chicoreus groschi 8\%, Cherithium lutosum 7\%, Cherithium torresi 7\%, Vittina sp. 2\%, Scylla sp. 3\%, Metopograpsus sp. 8\%, Clibanarius sp. 7\%, Uca sp. 10\%, Alpheus sp. 1\%, Parathelphusa convexa 6\%. Presentase terbesar yaitu $11 \%$ dari spesies Terebralia sulcata.

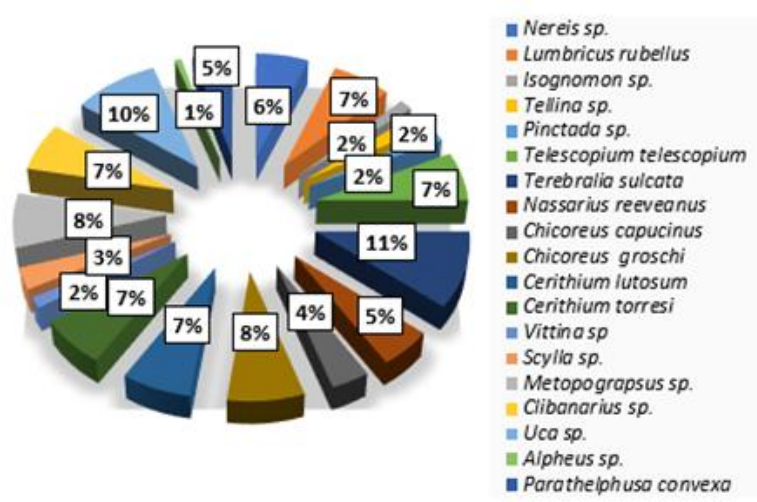

Gambar 2. Komposisi Jenis Makrozoobentos

\subsubsection{Kelimpahan dan Struktur Komunitas Makrozoobentos}

Hasil penelitian yang telah dilakukan di Tahura Ngurah Rai ditemukan beberapa jenis makrozoobentos yang mendiami kawasan tersebut. Stasiun I ditemukan 5 spesies yang memiliki komposisi jenis atau persentase kehadiran masingmasing spesies yaitu spesies Lumbricus rubellus $31 \%$, Clibanarius sp. $23 \%$, Vittina sp. sebesar $16 \%$, spesies Uca sp. dan Parathelphusa convexa memiliki persentase kehadiran yang sama sebesar $15 \%$.

Stasiun I memiliki tipe substrat lempung liat berpasir dimana tipe substrat ini banyak dihuni jenis cacing tanah atau Lumbricus rubellus. Jenis organisme ini merupakan jenis deposit feeder sesuai dengan Setiawan (2009) yang menyatakan bahwa kelas oligocaeta, polycaeta dan bivalvia banyak ditemukan pada substrat yang berlumpur. Spesies Vittina sp. hanya ditemukan di stasiun I hal ini dikarenakan salinitas pada stasiun I relatif rendah. Vittina sp. merupakan salah satu hewan yang hidup pada perairan tawar sampai payau 
Tabel 2.

Spesies dan kelimpahan makrozoobentos yang ditemukan di Tahura Ngurah Rai

\begin{tabular}{clcccc}
\hline Kelas & \multicolumn{1}{c}{ Nama Spesies } & Stasiun I & Stasiun II & Stasiun III & Stasiun IV \\
\hline Polychaeta & Nereis sp. & - & 2.4 & 2.4 & - \\
Oligochaeta & Lumbricus rubellus & 2.4 & 1.8 & 1.2 & - \\
Bivalvia & Isognomon sp. & - & - & 1.2 & - \\
& Tellina sp. & - & - & - & 1.8 \\
& Pinctada sp. & - & 1.2 & - & - \\
Gastropoda & Telescopium Telescopium & - & 3.6 & 0.6 & 1.2 \\
& Terebralia sulcate & - & 3.6 & 3 & 1.8 \\
& Nassarius reeveanus & - & - & 3 & 1.2 \\
& Chicoreus capucinus & - & 0.6 & 0.6 & 1.8 \\
& Chicoreus groschi & - & 1.2 & 1.8 & 3 \\
& Cerithium lutosum & - & 0.6 & - & 4.8 \\
& Cerithium torresi & - & - & - & 5.4 \\
& Vittina sp & 1.2 & - & - & - \\
Mcylla sp. & - & 1.2 & - & 1.2 \\
& Metopograpsus sp. & - & 1.2 & 1.2 & 3.6 \\
& Clibanarius sp. & 1.8 & 1.2 & 1.8 & 0.6 \\
& Uca sp. & 1.2 & 3 & 2.4 & 1.2 \\
& Alpheus sp. & - & 2.4 & - & - \\
& Parathelphusa convexa & 1.2 & 0.6 & - \\
\hline
\end{tabular}

dan ditemukan di saluran air atau sungai kecil $(\mathrm{Ng}$ et al., 2017).

Kelimpahan total spesies di stasiun I yaitu 7,8 ind $/ \mathrm{m}^{2}$ dari 5 spesies yang ditemukan. Hasil perhitungan indeks keanekaragaman pada stasiun I yaitu 1,57 dimana hasil perhitungan tersebut mengklasifikasikan bahwa stasiun I memiliki indeks keanekaragaman yang rendah. Sesuai dengan pernyataan Odum (1993) bahwa apabila nilai indeks keanekaragaman masuk dalam kategori rendah maka hal tersebut mengindikasikan bahwa perairan tersebut telah tercemar. Sedangkan nilai indeks keseragaman dan indeks dominansi pada stasiun I menurut Odum (1993) menandakan bahwa kondisi komunitas tersebut stabil dan tingkat dominansi pada stasiun I tergolong rendah.

Stasiun II berlokasi di dekat aliran anak sungai badung yang bermuara di Tahura Ngurah Rai. Pada stasiun II memiliki tipe substrat lempung berpasir dimana pada stasiun II ini ditemukan 13 spesies yang terbanyak diantara stasiun lainnya. Spesies yang jumlahnya terbanyak yaitu Terebralia sulcata dan Telescopim telscopium sedangkan spesies yang hanya ditemukan di stasiun II yaitu Pinctada sp. Di stasiun II ini juga mulai ditemukan spesies Nereis sp. dimana habitat spesies ini di substrat berlumpur. Sesuai dengan penelitian yang telah di lakukan oleh Ulfah et al., (2012) yang menemukan spesies Nereis sp. yang melimpah di substrat yang berlumpur dan juga merupakan kawasan pertemuan air tawar dengan air laut. Indeks keanekaragaman pada stasiun II memiliki nilai tertinggi diantara stasiun lain.

Kawasan Stasiun II ini merupakan kawasan yang sudah terpengaruh dengan pasang surut air laut. Hal ini didukung dengan data pengukuran kualitas air pada stasiun II, yaitu nilai salinitas 19 ppt. Nilai kelimpahan total pada stasiun II yaitu 24 ind $/ \mathrm{m}^{2}$. Nilai indeks keanekaragaman stasiun II yaitu 2,42. Nilai indeks tersebut menurut Odum (1993) termasuk dalam kategori sedang dan kestabilan perairan telah tercemar sedang. Nilai indeks keseragaman biota pada stasiun II yaitu 0,94 dan nilai indeks dominansi sebesar 0,1. Nilai keseragaman di stasiun II menurut Odum (1993) termasuk dalam kategori komunitas stabil. Sedangkan nilai indeks dominansinya tergolong rendah.

Stasiun III berlokasi di area tengah mangrove yang didominasi jenis mangrove rhizophora. Pengambilan data pada stasiun III ditemukan 12 spesies makrozoobentos yang berasal dari 5 kelas yaitu polychaeta, oligochaete, gastropoda, bivalvia, 
dan malacostraca. Spesies yang hanya ditemukan di stasiun III yaitu spesies Isognomon sp. yang berasal dari kelas bivalvia. Isognomon $\mathrm{sp}$ ditemukan dalam jumlah relatif sedikit. Hal ini dipengaruhi oleh sifat bivalvia sendiri yang menetap disuatu tempat sehingga memiliki toleransi yang lebih terbatas terhadap perubahan lingkungan dibandingkan kelas gastropoda (Purwiyanto, 2016).

Di stasiun III ditemukan 12 spesies makrozoobentos dengan kelimpahan total sebesar $19,8 \mathrm{ind} / \mathrm{m}^{2}$. Spesies makrozoobentos yang banyak ditemukan pada stasiun III yaitu Terebralia sulcata dan Nassarius reeveanus sebanyak $5 \mathrm{ind} / \mathrm{m}^{2}$. Pada stasiun III ini banyak ditemukan spesies makrozoobentos yang berasal dari kelas gastropoda dan Crustaceae yang memiliki toleransi yang tinggi terhadap perubahan lingkungan (Astrini et al,. 2014). Indeks keanekaragaman pada stasiun III sebesar 2,35 ind $/ \mathrm{m}^{2}$. Menurut Odum (1993) Nilai indeks keanekaragaman tersebut masuk dalam kategori sedang. Hal ini menandakan bahwa kondisi perairan kurang baik atau tercemar sedang. Nilai indeks keseragaman dan indeks dominansi pada stasiun III yaitu 0,95 dan 0,11. Nilai indeks keseragaman tersebut termasuk dalam kategori komunitas stabil. kategori indeks dominansi stasiun III yaitu rendah dimana pada stasiun III ini tidak terjadi dominansi salah satu spesies yang ditemukan di kawasan tersebut (Odum,1993).

Kelimpahan makrozoobentos pada stasiun IV memiliki nilai total sebesar $27,6 \mathrm{ind} / \mathrm{m}^{2}$. Jumlah spesies yang ditemukan pada stasiun ini sebanyak 12 spesies yang berasal dari kelas bivalvia, gastropoda dan crustacea. Stasiun IV ini berlokasi di area depan yaitu berhadapan langsung dengan laut. Di lokasi ini terdapat dua aliran yang berasal dari daratan. Aliran ini yang membawa air bersalinitas rendah ke laut. Pada aliran ini di temukan spesies Tellina sp. yang berasal dari kelas bivalvia dimana spesies Tellina sp. ini banyak ditemukan di kawasan pantai (Ochoa et al., 2014). Nilai indeks keanekaragaman pada stasiun IV yaitu 2,29 yang masuk dalam kategori sedang. Menurut Odum (1993) nilai indkes keanekaragaman makrozoobentos tersebut menggambarkan kestabilan perairan telah tercemar sedang. Sedangkan nilai indeks keseragaman pada stasiun IV sebesar 0,92 dan nilai indeks dominansinya sebesar 0,12 . Nilai indeks keseragaman makrozoobentos tersebut masih dalam kategori komunitas stabil dan nilai indeks dominansi masuk dalam kategori rendah. Hal ini menandakan bahwa ekosistem tersebut memiliki tingkat keanekaragaman yang tinggi dan tidak terjadi dominansi antar spesies (Odum, 1993).

Beberapa jenis makrozoobentos ditemukan hampir di semua stasiun seperti halnya Metopograpsus sp., Chicoreus sp. yang ditemukan di tiga stasiun. Metopograpsus sp. memiliki habitat atau tinggal di kawasan mangrove yang memiliki jenis substrat berlumpur. Tingkat mobilitas spesies ini tergolong tinggi dibandingkan spesies lain sehingga spesies ini bisa ditemukan hampir disemua stasiun (Bagus dan Anunurohim, 2013). Spesies Uca sp. dan Clibanarius sp. merupakan dua spesies berasal dari kelas crustacea yang ditemukan di semua stasiun. Uca sp. dan Clibanarius sp. merupakan dua spesies yang umum di temukan di daerah mangrove dan dapat menyebar luas secara vertikal dan horizontal (Pratiwi dan Widyastuti, 2013).

Hasil penelitian di Tahura Ngurah Rai ini ditemukan lima kelas makrozoobentos antara lain Polychaeta, Oligochaeta, Gastropoda, Bivalvia, dan Crustacea. Jumlah kelas yang ditemukan ini lebih banyak di bandingkan penelitian yang dilakukan oleh Rabiah et al., (2017) di ekosistem mangrove di kampung Nipah Sumatra Utara. Persentase kehadiran total individu tertinggi yaitu kelas gastropoda yaitu $49 \%$ dari total jumlah individu yang ditemukan. Hal ini diduga kelas gastropoda memiliki daya tahan hidup yang tinggi di setiap stasiun pengamatan. Gastrpoda merupakan hewan yang dapat hidup dan berkembang biak dengan baik pada berbagai jenis substrat yang memiliki kesediaan makanan dan kehidupannya di pengaruhi oleh fisika-kimia perairan (Rizka et al., 2016).

Tabel 3

Struktur Komunitas Makrozoobentos

\begin{tabular}{cccc}
\hline Stasiun & $\mathrm{H}^{\prime}$ & $\mathrm{e}$ & $\mathrm{C}$ \\
\hline I & 1.57 & 0.97 & 0.22 \\
II & 2.42 & 0.94 & 0.1 \\
III & 2.35 & 0.94 & 0.11 \\
IV & 2.3 & 0.92 & 0.12 \\
\hline
\end{tabular}

\subsection{Parameter Kualitas Air}

Pengukuran parameter fisika-kimia lingkungan ini dilakukan pada pagi hari dimana intensitas cahaya 
matahari yang diterima masih rendah dan kondisi perairan surut. Salinitas perairan yang merupakan parameter kimia perairan memiliki nilai yang bervariasi antar stasiun. Hasil pengukuran salinitas perairan pada stasiun I sebesar $17 \mathrm{ppt}$, pada stasiun II dan III memiliki hasil pengukuran yang sama sebesar 19 ppt. Pada stasiun IV hasil pengukuran menunjukkan angka 19,8 ppt.

Tabel 4

Hasil Pengukuran Parameter Kualitas Air

\begin{tabular}{cccccc}
\hline \multirow{2}{*}{ No } & \multirow{2}{*}{ Parameter } & \multicolumn{4}{c}{ Stasiun } \\
& & I & II & III & IV \\
\hline 1 & pH & 7.8 & 7.7 & 7.6 & 7.7 \\
2 & DO & 4 & 5.4 & 4.6 & 3.8 \\
3 & Salinitas & 17 & 19 & 19 & 19.8 \\
4 & Kekeruahan & 31.5 & 10.4 & 14.6 & 15.4 \\
5 & Suhu & 28 & 28.5 & 28.7 & 28.7 \\
\hline
\end{tabular}

Hasil pengukuran salinitas terendah yaitu pada stasiun I dimana pada stasiun I merupakan daerah dekat dengan pemukiman warga dan terdapat sungai kecil yang dialiri air tawar sehingga salinitas di stasiun I sudah terpengaruh dengan air tawar. Stasiun IV merupakan stasiun yang memiliki kadar salinitas tertinggi hal ini dikarenakan daerah stasiun IV yang berhadapan langsung dengan laut. Salinitas untuk kawasan payau atau ekosistem mangrove berkisar 0-28ppt (Choirudin et al., 2014).

$\mathrm{pH}$ perairan Tahura Ngurah Rai bervariasi, pada stasiun I yang terletak di kawasan dekat dengan pemukiman memiliki $\mathrm{pH}$ rata-rata sebesar 7,8. Nilai $\mathrm{pH}$ pada stasiun II yang berlokasi di kawasan aliran sungai yang masuk ke kawasan mangrove memiliki nilai $\mathrm{pH}$ sebesar 7,7. Stasiun III yang berlokasi dikawasan tengah mangrove memiliki nilai kisaran $\mathrm{pH}$ sebesar 7,6 dan stasiun IV yang berada pada kawasan depan yang menghadap arah laut memiliki nilai kisaran $\mathrm{pH}$ sebesar 7,7. Semua stasiun yang telah diteliti memiliki perbedaan nilai rata-rata $\mathrm{pH}$ tidak jauh berbeda. Rentangan $\mathrm{pH}$ pada empat stasiun yaitu 7,6 - 7,8 dimana rentangan tersebut masih tergolong normal dan rentangan $\mathrm{pH}$ tersebut tidak jauh berbeda dengan hasil pengukuran yang di lakukan di ekosistem mangrove pulau Sembilan Sumatra utara oleh Nasution et al., (2016). Bagi biota akuatik seperti krustasea $\mathrm{pH}$ tersebut tidak kurang dari 5 dan tidak lebih dari 9 akan menguntungkan untuk kehidupannya (Pratiwi, 2010).

Hasil pengukuran oksigen terlarut (DO) di Tahura Ngurah Rai memiliki rata-rata yang variatif pada tiap-tiap stasiun. Nilai hasil pengukuran DO yang terendah pada stasiun IV dengan rata-rata $3,8 \mathrm{mg} / \mathrm{L}$. Sedangkan hasil pengukuran tertinggi terdapat pada stasiun II. Oksigen terlarut pada stasiun II memiliki rata-rata sebesar 5,4 mg/L yang diatas ambang batas baku mutu kualitas air. Ambang batas baku mutu kualitas air laut untuk DO $>5 \mathrm{mg} / \mathrm{L}$ (Kepmen LH No.51, 2004). Nilai DO ke-empat stasiun tergolong rendah hal ini di karenakan kawasan Tahura Ngurah merupakan kawasan muara sungai dimana dalam perairan terkandung bahan organik yang tinggi. Tingginya bahan organik tersebut membuat aktivitas bakteri pengurai tinggi. Selain itu cuaca setelah hujan pada saat pengukuran DO berpengaruh terhadap rendahnya nilai DO. Rendahnya DO diakibatkan oleh partikel tersuspensi yang tinggi pada perairan (Situmorang et al., 2015).

Hasil pengukuran suhu di Tahura Ngurah Rai menunjukkan nilai rata-rata yang tidak jauh berbeda antar empat stasiun. Rata-rata suhu sebesar $28^{\circ} \mathrm{C}$ sampai $28,7{ }^{\circ} \mathrm{C}$. Hasil pengukuran suhu tersebut masih dalam kategori normal untuk kehidupan biota air sehingga tidak berpengaruh terhadap keberadaan makrozoobentos di Tahura Ngurah Rai. Hal ini sesuai dengan keputusan Kepmen LH No.51 (2004) dimana suhu optimum untuk biota di estuaria berkisar antara $28-30^{\circ} \mathrm{C}$.

Hasil pengukuran kekeruhan di masingmasing stasiun yaitu pada stasiun I sebesar 31,5 NTU. Hasil pengukuran pada stasiun I tersebut sudah melewati ambang batas kekeruhan bagi kehidupan biota akuatik. Hal ini disebabkan lokasi stasiun I yang berada dekat dengan pemukiman. Menurut Hasan (2012) kekeruhan tinggi diakibatkan banyaknya bahan organik dari rumah tangga yang tersuspensi ke perairan. Ambang batas maksimum kekeruhan untuk kehidupan biota akuatik yaitu 30 NTU (Setiawan, 2013). Hasil pengukuran kekeruhan pada stasiun II, III dan IV masih dalam ambang batas kekeruhan untuk kehidupan biota akuatik.

\subsection{Tipe Substrat}

Perbedaan tipe substrat pada kawasan yang berbeda. Berdasarkan hasil penelitian yang telah 
dilakukan tipe substrat di kawasan Tahura Ngurah Rai ada 3 kategori yaitu lempung liat berpasir, lempung berpasir, lempung berliat. Tipe substrat pada stasiun I masuk dalam kategori lempung liat berpasir yang tersusun dari 53,81\% pasir, debu $21,54 \%$, liat $24,65 \%$. Tipe substrat pada stasiun ini berpengaruh terhadap kelimpahan makrozoobentos. Kelimpahan makrozoobentos yang rendah di stasiun I ini di pengaruhi oleh tipe substrat tersebut. Tipe substrat lempung liat ditemukan sedikit jenis makrozoobentos (Zulkifli dan Setiawan, 2017). Tipe substrat yang didominasi oleh lumpur dan pasir halus menurut Nybakken (1992) dalam Ulfah (2012) kurang baik bagi pertumbuhan organisme akuatik karena proses dekomposisi yang terjadi pada substrat tersebut secara anaerobik yang dapat menimbulkan bau serta bersifat toksik dan menyebabkan tercemarnya perairan.

Tabel 5.

Tipe Substrat

\begin{tabular}{ccccc}
\hline \multirow{2}{*}{ Tekstur } & \multicolumn{4}{c}{ Stasiun } \\
& I & II & III & IV \\
\hline Pasir (\%) & 53.81 & 74.03 & 42.4 & 74.56 \\
Debu (\%) & 21.54 & 9.09 & 30.36 & 21.55 \\
Liat (\%) & 24.65 & 16.88 & 27.24 & 3.89 \\
& Lempung & Lempung & Lempung & Lempung \\
Kategori & Liat & Berpasir & Berliat & Berpasir \\
& Berpasir & & & \\
\end{tabular}

Tipe substrat pada stasiun II yaitu lempung berpasir yang tersusun dari pasir $74,03 \%$, debu $9,09 \%$, dan liat $16,88 \%$. Pada stasiun II ini kandungan pasir di substrat hampir tiga per empat bagian. Substrat berpasir ini menandakan bahwa substrat ini mengandung butiran yang lebih besar. Menurut Putri et al., (2017) dalam penelitiannya menyebutkan bahwa kandungan pasir pada substrat berbanding lurus dengan kelimpahan makrozoobentos, semakin tinggi kandungan pasir maka akan semakin tinggi kelimpahan makrozoobentos.

Tipe substrat pada stasiun III berdasarkan hasil penelitian masuk dalam kategori lempung berliat yang tersusun dari pasir $42,4 \%$, debu $30,36 \%$, liat $27,24 \%$. Komposisi penyusun substrat pada stasiun III memiliki kandungan yang hampir seimbang. Hasil uji substrat pada stasiun IV menunjukkan bahwa substrat pada stasiun IV masuk dalam kategori lempung berpasir sama dengan stasiun II.
Perbedaan stasiun II dengan stasiun IV ini adalah pada persentase penyusunnya. Pada stasiun IV kandungan pasir sebesar $74,56 \%$, debu $21,55 \%$, liat $3,89 \%$. Kandungan debu dan pasir pada stasiun IV lebih banyak dibandingkan stasiun II dan kandungan liatnya lebih sedikit dibandingkan stasiun II. Hal ini dipengaruhi daerah stasiun IV yang berada di kawasan pantai. Menurut Hawari dan Amin (2014) pada perairan terbuka akan didominasi fraksi pasir diakibatkan adanya kecepatan arus yang cukup kuat.

Kandungan pasir yang tinggi pada substrat berpengaruh terhadap kelimpahan makrozoobentos. Pada Stasiun II, III, dan IV memiliki persemtase kandungan pasir yang tinggi serta memiliki nilai kelimpahan total yang tinggi. Hal ini sesuai dengan penelitian Ritniasih dan Wibowo (2010) kelimpahan tertinggi bivalvia dan gastropoda ditemukan pada stasiun yang berada di kawasan pasang surut sehingga didominasi fraksi pasir selain itu memiliki kandungan bahan organik yang rendah.

\subsection{Analisis Regresi}

Berdasarkan hasil analisis regresi parameter lingkungan fisika-kimia dengan kelimpahan makrozoobentos dari ke empat stasiun yang menunjukkan pengaruhnya yaitu suhu, salinitas dan kekeruhan. Hasil analisis regresi antara salinitas sebagai sumbu $X$ dengan kelimpahan makrozoobentos sebagai sumbu $\mathrm{Y}$ menghasilkan nilai $R$ square sebesar 0,9603 . Hasil tersebut menerangkan bahwa nilai koefisien determinasinya sebesar $96 \%$ atau pengaruh salinitas terhadap kelimpahan makrozoobentos relatif besar. Menurut Choirudin et al., (2014) salinitas memiliki pengaruh terhadap keberadaan dan jumlah makrozoobentos pada muara sungai terutama polychaeta.

Hasil analisis regresi antara suhu sebagai variable $X$ dengan kelimpahan makrozoobentos sebagai variable $\mathrm{Y}$ menunjukkan adanya pengaruh yang besar. Pengaruh kenikan atau penurunan suhu sendiri sesuai dari hasil yaitu $78 \%$ terhadap kelimpahan makrozoobentos yang diteliti di Tahura Ngurah Rai. Nilai 78\% tersebut di peroleh dari perhitungan dengan memperoleh nilai $\mathrm{R}$ square sebesar 0,7844 . Hal tersebut sesuai dengan hasil penelitian Septiani et al., (2015) di sungai Mruwe Yogyakarta yang meregresikan faktor kimia-fisika dengan faktor biologi. Hasil regresi 

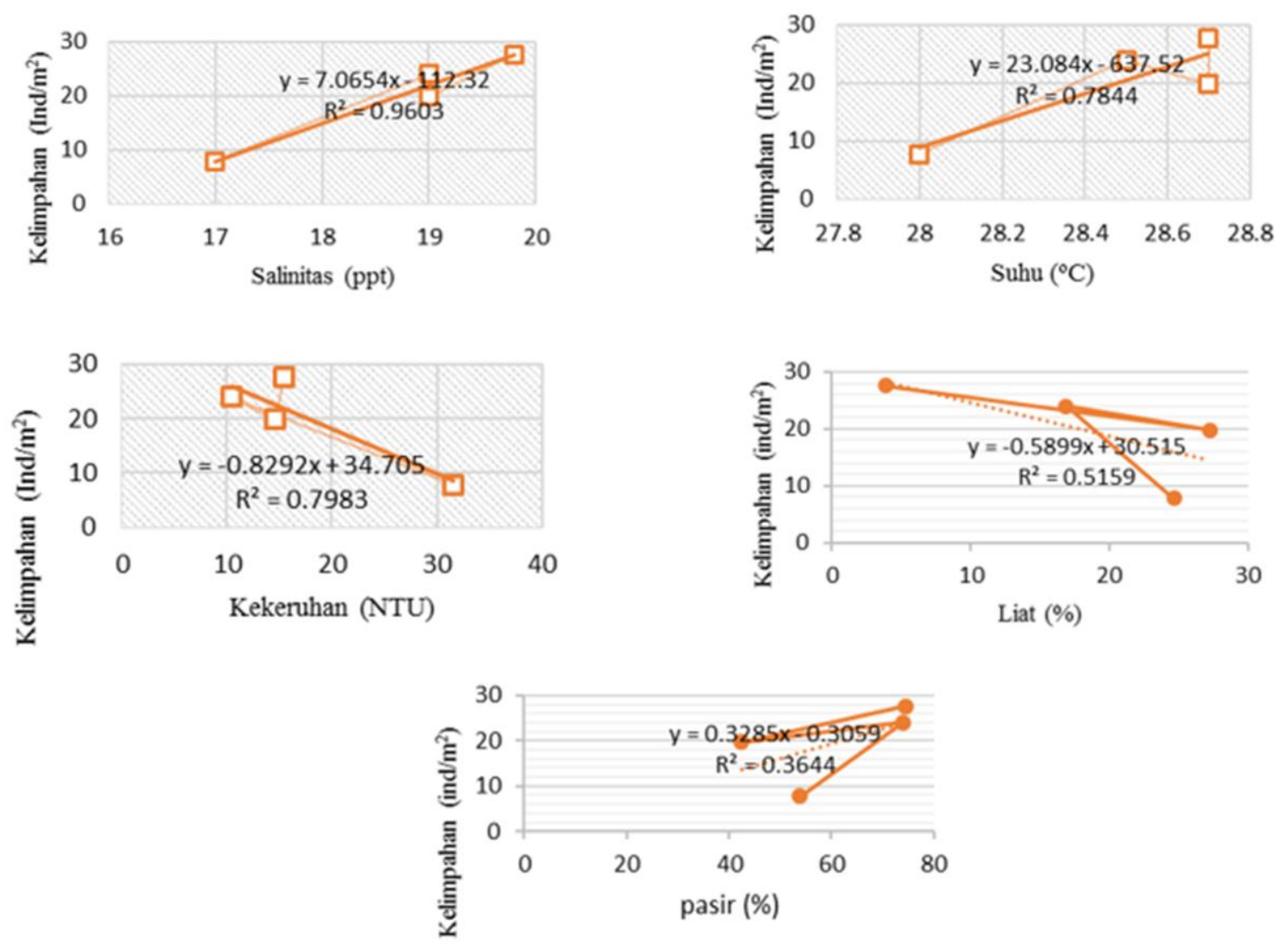

Gambar 3. Regresi kelimapahan makrozoobentos dengan parameter kualitas air dan substrat salinitas, suhu, kekeruhan, liat, pasir.

menunjukkan pengaruh terbesar adalah suhu dan kecepatan arus air.

Kekeruhan memiliki pengaruh yang hampir sama besarnya terhadap kelimpahan makrozoobentos berdasarkan hasil analisis regresi. Hasil dari analisis regresi antara kekeruhan dengan kelimpahan makrozoobentos sebesar 79\%. Nilai R square yang diperoleh dari hasil analisis tersebut yaitu 0,7983. Kelimpahan gastropoda di Tahura Ngurah Rai di pengaruhi oleh kekeruhan. Keberadaan gastropoda dipengaruhi oleh faktor lingkungan antara lain salinitas, kekeruhan.

Peran gastropoda sendiri yaitu sebagai biota penyaring bahan organik dalam perairan atau feeder yang mempengaruhi kekeruhan perairan. Sedangkan makrozoobentos ditemukan di perairan yang bersalinitas 18 ppt-23 ppt (Hawari dan Amin, 2014). Nilai regresi antara makrozoobentos dengan $\mathrm{pH}$ dan $\mathrm{DO}$ memiliki nilai koefisien determiasi sebesar $32 \%$ dan $5 \%$. Nilai tersebut menunjukkan bahwa $\mathrm{pH}$ dan $\mathrm{DO}$ kurang berpengaruh terhadap kelimpahan makrozoobentos.
Sesuai dengan hasil penelitian Mushthofa et al., (2014) selama DO masih dalam ambang batas maka tidak berpengaruh untuk kehidupan makrozoobenthos. Hal ini tidak terlepas dari adanya banyaknya masukan bahan limbah organik ke perairan yang dapat pula mempengaruhi kadar $\mathrm{pH}$ maupun DO pada perairan.

Hasil regresi antara kandungan liat sebagai variabel $X$ dengan kelimpahan makrozoobentos sebagai variabel $\mathrm{Y}$ menghasilkan nilai $\mathrm{R}^{2}$ sebesar $52 \%$. Nilai tersebut memiliki pengaruh yang cukup besar terhadap keberadan makrozoobentos. Dengan nilai koefisien korelasi sebesar $-72 \%$ yang menunjukkan hubungan negatif. Semakin tinggi kandungan liat maka semakin rendah kelimpahan makrozoobentos (Onrizal et al., 2012).

Nilai regresi antara kandungan pasir sebagai variabel $\mathrm{X}$ dengan kelimpahan makrozoobentos sebagai variabel $\mathrm{Y}$ sebesar $36 \%$. Hal ini menunjukkan pengaruh kandungan pasir sebesar $36 \%$ terhadap kelimpahan makrozoobentos sedangkan $54 \%$ dipengaruhi oleh faktor lain. Koefisien korelasi sebesar $60 \%$ yang menunjukkan hubungan positif. Nilai koefisien tersebut 
menunjukan hubungan kandungan pasir terhadap kelimpahan makrozoobentos, semakin tinggi kandungan pasir maka semakin tinggi kelimpahan makrozoobentos. Hal ini sesuai dengan hasil penelitian Onrizal et al. (2012) bahwa hasil analisis korelasi antara makrooobentos dengan kandungan pasir berbanding lurus.

\section{Simpulan}

Berdasarkan hasil penelitian yang telah dilakukan Di Taman Hutan Raya Ngurah Rai Bali dapat disimpulkan bahwa Makrozoobentos yang ditemukan di Tahura Ngurah Rai terdiri dari 5 kelas yaitu Polychaeta, Oligochaeta, Bivalvia, Gastropoda, dan Crustacea. Spesies yang banyak dijumpai adalah kelas Gastropoda dan Crustacea. Indeks keanekaragaman $\left(\mathrm{H}^{\prime}\right)$ makrozoobentos di stasiun I dalam kategori rendah, sedangkan stasiun II-IV dalam kategori sedang. Indeks keseragaman (E) pada ke- empat stasiun termasuk dalam kategori komunitas stabil. Hasil perhitungan indeks dominansi (C) pada ke-empat stasiun yaitu termasuk tingkat dominasi rendah.

Nilai parameter fisika-kimia perairan di Tahura Ngurah Rai pada ke- empat stasiun masih dalam batas normal baku mutu kualitas air payau kecuali nilai kekeruhan stasiun I yang melebihi batas normal baku mutu kualitas perairan. Tipe substrat pada stasiun I-IV berturut-turut yaitu lempung liat berpasir, lempung berpasir, lempung berliat, lempung berpasir.

Parameter perairan yang berpengaruh terhadap kelimpahan makrozoobentos adalah salinitas, suhu, kekeruhan. Tipe substrat yang berpengaruh terhadap kelimpahan makrozoobentos adalah tipe substrat yang banyak mengandung liat dan pasir.

\section{Ucapan Terimakasih}

Terimkasih kepada Ibu Nurhayati, Bapak Simon dan jajaran staff Tahura Ngurah Rai yang telah membantu dalam proses pengumpulan data.

\section{Daftar Pustaka}

Astrini, A. D. R., Yusuf, M. \& Santoso, A. (2014). Kondisi Perairan Terhadap Struktur Komunitas Makrozoobenthos Di Muara Sungai Karanganyar Dan Tapak, Kecamatan Tugu, Semarang. Journal of Marine Research, 3, 27-36.

Bagus, K. S. \& Anunurohim. (2013). Studi distribusi makrofauna benthos di zonasi mangrove Pulau
Poteran, Madura, Jawa Timur. Jurnal Sains dan Seni Pomits, 2(1), 1-5.

Choirudin, I. R., Supardjo, M. N. \& Muskananfola, M. R. (2014). Studi Hubungan Kandungan Bahan Organik Sedimen dengan Kelimpahan Makrozoobenthos di Muara Sungai Wedung Kabupaten Demak. Management of Aquatic Resources Journal, 3(3), 168-176.

English, S., C. Wilkinson \& V. Baker. (1994). Survey Manual for Tropical Marine Resources. Townsville, Ausralia: Australian Institute of Marine Science.

Hawari, A. \& Amin, B. (2014). Hubungan Antara Bahan Organik Sedimen Dengan Kelimpahan Makrozoobenthos Di Perairan Pantai Pandan Provinsi Sumatera Utara. Jurnal Online Mahasiswa (JOM) Bidang Perikanan dan Ilmu Kelautan, 1(2), 1-11.

Hasan, Z. (2012). Hubungan Antara Karakteristik Substrat Dengan Struktur Komunitas Makrozoobenthos Di Sungai Cantigi, Kabupaten Indramayu. Jurnal Perikanan Kelautan, 3(3), 221-227.

Kementerian Lingkungan Hidup. (2004). Keputusan Menteri Negara Lingkungan Hidup Nomor: 51 Tahun 2004 tentang Baku Mutu Air Laut. Jakarta.

Mushthofa, A., Rudiyanti, S. \& Muskanonfola, M. R. (2014). Analisis Struktur Komunitas Makrozoobenthos Sebagai Bioindikator Kualitas Perairan Sungai Wedung Kabupaten Demak. Management of Aquatic Resources Journal, 3(1), 81-88.

Mentari, L. \& Muskananfola, M. R. (2015). Distribusi Kelimpahan Makrozoobentos Dan Kandungan Bahan Organik Serta Tekstur Sedimen Pada Muara Sungai Wakak, Kabupaten Kendal. Management of Aquatic Resources Journal, 4(4), 19-23.

Nasution, N. A., Djayus, Y. \& Mutadi, A. (2016). Sruktur Komunitas Makrozoobenthos Di Dusun Ii Desa Pulau Sembilan Kecamatan Pangkalan Susu Kabupaten Langkat Provinsi Sumatera Utara. AQUACOASTMARINE, 14(4), 11-18.

Ng, T. H., Dulipat, J., Foon, J. K., Lopes-Lima, M., Zieritz A. \& Liew, T. S. (2017). A preliminary checklist of the freshwater snails of Sabah (Malaysian Borneo) deposited in the BORNEENSIS collection, Universiti Malaysia Sabah. ZooKeys 673, 105-123.

Ochoa, J., Paz, V. \& Lewis, H. (2014). The archaeology and palaeobiological record of Pasimbahan-Magsanib Site, northern Palawan, Philippines. Philippines Sciene Letters, 7(1), 22-36.

Odum, E. P. (1993). Dasar-dasar Ekologi. Edisi Ketiga. Diterjemahkan oleh T. Samingan. Yogyakarta, Indonesia: Gadjah Mada University Press.

Odum, E. P. (1994). Dasar-dasar Ekologi. Edisi Ketiga. Yogyakarta, Indonesia: Gadjah Mada University Press. 
Pratiwi, R. (2010) Asosiasi krustasea di ekosistem padang lamun perairan Teluk Lampung. Ilmu Kelautan, 14 (2), 66-76.

Pratiwi, R. \& Widyastuti, E. (2013). Pola Sebaran dan Zonasi Krustasea Di Hutan Bakau Perairan Teluk Lampung. Jakarta. Zoo Indonesia, 22, 11-21.

Purwiyanto, A. I. S. (2016). Hubungan Nitrat, Fosfat Dan Ammonium Terhadap Keberadaan Makrozoobentos Di Perairan Muara Sungai Lumpur Kabupaten Ogan Komering Ilir Sumatera Selatan. Maspari Journal, 8(2), 101-110.

Putri, A. M. S., Suryanti, S. \& Widyorini, N. (2017). Hubungan Tekstur Sedimen Dengan Kandungan Bahan Organik Dan Kelimpahan Makrozoobenthos Di Muara Sungai Banjir Kanal Timur Semarang. Jurnal Saintek Perikanan, 12(1), 75-80.

Rabiah, R., Kardhinata, E. H. \& Karim, A. (2017). Struktur Komunitas Makrozoobentos Di Kawasan Rehabilitasi Mangrove Dan Mangrove Alami Di Kampung Nipah Kabupaten Serdang Bedagai Sumatera Utara. BIOLINK (Jurnal Biologi Lingkungan, Industri, Kesehatan), 3(2), 126-140.

Riniatsih, I. \& Wibowo, E. (2010). Substrat dasar dan parameter oseanografi sebagai penentu keberadaan gastropoda dan bivalvia di Pantai Sluke Kabupaten Rembang. ILMU KELAUTAN: Indonesian Journal of Marine Sciences, 14(1), 50-59.

Rizka, S., Muchlisin, Z. A., Akyun, Q., Fadli, N., Dewiyati, I. \& Halim, A. (2016). Komunitas Makrozoobentos Di Perairan Estuaria Rawa Gambut Tripa Provinsi Aceh. Jurnal Ilmiah Mahasiswa Kelautan Perikanan Unsyiah, 1(1), 134-145.

Rumada, I. W., Kesumadewi, A. I. \& Suyarto, R. (2015). Interpretasi Citra Satelit Landsat 8 Untuk Identifikasi Kerusakan Hutan Mangrove di Taman Hutan Raya Ngurah Rai Bali. E-Jurnal Agroekoteknologi Tropika, 4(3), 234-243.
Septiani, B. Y. A. (2015). Keanekaragaman Jenis Makrozoobentos Sebagai Penentu Kualitas Air Sungai Mruwe Yogyakarta. Jurnal Teknobiologi, 6, 1-11.

Setiawan, D. (2008). Struktur komunitas makrozoobentos sebagai bioindikator kualitas lingkungan perairan hilir Sungai Musi. Skripsi. Bogor, Indonesia: Institut Pertanian Bogor.

Setiawan, D. (2009). Studi komunitas makrozoobenthos di perairan hilir Sungai Lematang sekitar daerah pasar bawah Kabupaten Lahat.Jurnal Penelitian Sains, 9, 12-14.

Setiawan, H. (2013). Status ekologi hutan mangrove pada berbagai tingkat ketebalan. Jurnal Penelitian Kehutanan Wallacea, 2(2), 104-120.

Situmorang, D. P. P., Sitorus, H. \& Desrita, D. (2015). Macrozoobentos Community in Percut River, Percut Sei Tuan District, Deli Serdang Regency, North Sumatera. AQUACOASTMARINE, 7(2), 10.

Onrizal, O., Simarmata, F. S. \& Wahyuningsih, H. (2012). Keanekaragaman Makrozoobenthos pada Hutan Mangrove yang Direhabilitasi di Pantai Timur Sumatera Utara. Jurnal Natur Indonesia, 11(2), 94-103.

Sugiyono, P. (2005). Memahami Penelitian Kualitatif. (edisi 8). Bandung, Indonesia: Alfabeta.

Tarigan, M. S. (2010). Sebaran dan luas hutan mangrove di wilayah pesisir teluk pising utara Pulau Kabaena Provinsi Sulawesi Tenggara. Makara Journal of Science. 12(2), 108-112.

Ulfah, Y., Widianingsih, W. \& Zainuri, M. (2012). Struktur Komunitas Makrozoobenthos di Perairan Wilayah Morosari Desa Bedono Kecamatan Sayung Demak. Journal of Marine Research, 1(2), 188-196.

Zulkifli, H. \& Setiawan, D. (2017). Struktur komunitas makrozoobentos di perairan sungai musi kawasan Pulokerto sebagai instrumen biomonitoring. Jurnal Natur Indonesia, 14(1), 95-99.

(C) 2017 by the authors; licensee Udayana University, Indonesia. This article is an open access article distributed under the terms and conditions of the Creative Commons Attribution license (http://creativecommons.org/licenses/by/3.0/). 